\title{
Association of a missense mutation in the luteinizing hormone/choriogonadotropin receptor gene (LHCGR) with superovulation traits in Chinese Holstein heifers
}

Yong $\mathrm{Yu}^{\dagger}$, Yunwei Pang ${ }^{\dagger}$, Haichao Zhao ${ }^{\dagger}$, Xiaoling Xu, Zhonghong Wu, Lei An and Jianhui Tian ${ }^{*}$

\begin{abstract}
Background: Upon binding luteinizing hormone in the ovary, the luteinizing hormone/choriogonadotropin receptor (LHCGR) is necessary for follicular maturation and ovulation, as well as luteal function. We detected mutations in the LHCGR gene and evaluated their association with superovulation.
\end{abstract}

Methods: Using polymerase chain reaction-single strand conformation polymorphism (PCR-SSCP) and DNA sequencing, we examined polymorphisms in LHCGR and the genotypes associated with superovulation traits in 127 Chinese Holstein heifers.

Results: A G/T polymorphism (ss52050737) in exon 11 was significantly associated with the total number of ova and the number of transferable embryos.

Conclusions: LHCGR may be a new predictor for superovulation in Chinese Holstein heifers.

Keywords: Chinese Holstein heifer, LHCGR, SNP, Superovulation

\section{Background}

In cattle, the pituitary gonadotropin luteinizing hormone (LH) plays a role in follicular development [1], ovulation $[1,2]$, corpora lutea formation [3], and preimplantation embryonic development $[4,5]$. The cellular actions of LH are mainly mediated by the luteinizing hormone/choriogonadotropin receptor (LHCGR), which has features typical of receptors that interact with $G$ proteins, including a cellular domain, seven transmembrane domains, and an extracellular hormone-binding domain [6]. LHR cDNAs have been cloned in several species [7-10], and several mRNA variants have been reported [11-15]. In cattle, LHR splice variants have been reported with deletions of exon 10 and partial deletions of exon 11 or exon $3[14,15]$. The former two variants are found significantly more frequently in

\footnotetext{
* Correspondence: tianjh@cau.edu.cn

${ }^{\dagger}$ Equal contributors

Key Laboratory of Animal Genetics and Breeding of the Ministry of

Agriculture, College of Animal Science and Technology, China Agricultura University, Beijing 100193, PR China
}

cultured granulosa cells compared with cells from dominant follicles [14].

The technologies for achieving multiple ovulation and embryo transfer (MOET) are well established, and more than 500,000 embryos are produced annually from superovulated cows worldwide [16]. However, variability in the superovulation response among individuals continues to be one of the most frustrating problems with respect to embryo transfer in cattle [17]. Although great progress has been made toward understanding folliculogenesis and regulation of the hypothalamic-pituitarygonadal axis, and many approaches to superovulatory treatments have been explored, the high variability among individuals in ovarian responsiveness to the application of exogenous hormones remains a challenge. One reason for this variability is that superovulation traits are quantitative and are strongly affected by the environment. Adjustments to superovulation protocols related to luteinizing hormone/choriogonadotropin receptor (LHCGR) availability may increase the yield of bovine embryos [18]. The follicle stimulating hormone 
receptor $(F S H R)$, inhibin alpha (INHA) and progesterone receptor $(P G R)$ genes have been reported as predictors of superovulation in Chinese Holstein cows [19-21]. In addition, three single-nucleotide polymorphisms (SNPs) in exon 11 of the LHCGR gene are associated with bovine fertility traits [22], and four SNPs of G51656T, A51703G, A51726G and G51737A in intron 9 of the LHCGR gene had significant effects on the total number of ova (TNO) recovered from superovulated Holstein cows [23]. Therefore, LHCGR was examined further as a candidate gene for predicting response to superovulation in Chinese Holstein heifers. The objective of this study was to investigate the prognostic significance of $L H C G R$ genotypes in superovulation responsiveness.

\section{Methods}

\section{Experimental animals and sampling}

A total of 127 Chinese Holstein heifers from 60.6 to 68.7 week of age old were obtained from four breeding farms of Beijing Dairy Cattle Center and used for superovulation treatment (see below). Blood samples were collected form each heifer aseptically from the caudal vein into a tube containing EDTA (ethylene diamine tetraacetic acid) as an anticoagulant. Genomic DNA was extracted using the RelaxGene Blood DNA System (Tiangen, Biotech, Co. Ltd.) and stored at $-20^{\circ} \mathrm{C}$.

\section{Superovulation and embryo harvest}

Superovulation was induced throughout the year except for the months of June, July and August using a 4-day regimen of decreasing doses (i.e. dose of $75,75,50,50$, $30,30,10$ and $10 \mathrm{mg}$ for each injection) of follicle stimulating hormone (Folltropin-V; Vetrepharm Canada Inc. , Belleville, ON, Canada) given at $12 \mathrm{~h}$ intervals beginning on day 4 after insertion of an intravaginal progesteronereleasing device (Day 0; CIDR, Inter Ag). A dose of 0.4 mg Prostaglandin F2 $\alpha$ (Shanghai Institute of Planned Parenthood Research; SIPPR, Shanghai, China) was given to each heifer on the morning of day 6 , and the CIDR device was removed that afternoon. Estrus was detected visually on the morning of day 8 . At approximately 7:00 p.m. on day 8 , each heifer was randomly artificially inseminated (AI) with the first of two straws from one of eight bulls containing sexed frozen-thawed sperm. AI with the second straw was performed $12 \mathrm{~h}$ later. On day 16, each uterine horn was flushed nonsurgically with $500 \mathrm{ml}$ Dulbecco's phosphate-buffered saline and the recovered fluid was examined for oocytes or embryos under a stereomicroscope. Embryos were isolated and classified as transferable embryos or degenerating embryos according to the criteria of the International Embryo Transfer Society (IETS). Oocytes were defined as unfertilized ova. Heifers with no oocytes or embryos were defined as non-responders.

\section{Primer design and PCR amplification}

Primer set 1 (sense: $5^{\prime}$-CTGAGTGGCTGGGATTAT-3'; anti-sense: $5^{\prime}$-CGGGAGGGCTTATTTGAT-3') was designed to amplify exon 11 of the LHCGR [accession: ID281900] gene. Primer set 2 (sense: $5^{\prime}$-GCTCTACCT GCTGCTCAT-3'; anti-sense: 5'-TAATTGCTGACACC CACA-3 ${ }^{\prime}$ ) was designed for genotyping the detected SNP (ss52050737). PCR was performed in a $20 \mu \mathrm{L}$ reaction containing $0.1 \mu \mathrm{m} / \mathrm{L}$ each primer, $4 \mu \mathrm{m} / \mathrm{L}$ dNTPs (deoxyribonucleoside triphosphates), $2 \mu \mathrm{L} 10 \times$ PCR buffer (containing $\mathrm{Mg}^{2+}$ ), 0.5 U TaKaRa Taq polymerase (TaKaRa Biotechnology, Co. Ltd.), and 50 ng genomic DNA as template. PCR reactions consisted of denaturation at $95^{\circ} \mathrm{C}$ for $5 \mathrm{~min}$, followed by 35 cycles of $95^{\circ} \mathrm{C}$ for $30 \mathrm{sec}$, annealing for $30 \mathrm{sec}$ at $57^{\circ} \mathrm{C}$ for primer set 1 and primer set 2 , and extension at $72^{\circ} \mathrm{C}$ for $70 \mathrm{sec}$ for primer set 1 and $30 \mathrm{sec}$ for primer set 2, followed by a final extension at $72^{\circ} \mathrm{C}$ for $5 \mathrm{~min}$. PCR products were analyzed with $1 \%$ agarose gel electrophoresis in TAE buffer $\left(0.89 \mathrm{~mol} / \mathrm{L}\right.$ Tris, $0.02 \mathrm{~mol} / \mathrm{L} \mathrm{Na}_{2}$ EDTA, $0.89 \mathrm{~mol} / \mathrm{L}$ boric acid) and stained with ethidium bromide.

\section{DNA sequencing and genotyping}

Amplified products from individual samples using primer set 1 were mixed and sequenced commercially (Invitrogen Beijing Office, Beijing, China). The mutation detected was genotyped by PCR-SSCP using primer set 2. PCR products $(3 \mu \mathrm{L})$ were mixed with $8 \mu \mathrm{L}$ denaturing solution ( $95 \%$ formamide, $25 \mathrm{mmol} / \mathrm{L}$ EDTA, $0.025 \%$ xylene-cyanol, $0.025 \%$ bromophenol blue), heated for 10 min at $98^{\circ} \mathrm{C}$, and chilled on ice. Denatured DNA was subjected to $13 \%$ polyacrylamide gel electrophoresis (PAGE) (39:1 acrylamide/bisacrylamide) in 1× Trisborate EDTA (TBE) buffer at constant voltage $(120 \mathrm{~V})$ for $8-10 \mathrm{~h}$. The gel was stained with $0.1 \%$ silver nitrate, and products with different electrophoresis patterns were sequenced in both directions.

\section{Statistical analysis}

Association of the genotype of the mutation with superovulation traits was calculated using the General Linear Model of PASW Statistics 18 (SPSS Inc. , Chicago, Illinois, USA). The factors considered were genotype, yard, age, season, and bull. The statistical model was

$$
Y_{j k h i}=u+G_{j}+A_{k}+S_{h}+D_{i}+B_{l}+e_{j k h i l}
$$

where $Y_{\text {jkhi }}$ was the phenotypic value of traits, $u$ was the population mean, $G_{\mathrm{j}}$ was the fixed effect of genotypes, $A_{\mathrm{k}}$ was the effect of age and acted as a covariate, $S_{\mathrm{h}}$ was the fixed effect of season (spring, autumn and winter), $D_{\mathrm{i}}$ was the effect of the yard, $B_{1}$ was the effect of the bull and acted as a random variable, and $e_{j \mathrm{khil}}$ was the random 
residual error. For the TNO, the factor of the bull was removed from the model.

\section{Results}

\section{Genotypic and allelic frequencies}

After DNA sequencing, we found a single mutation (ss52050737) in the 1049 bp fragment amplified with primer set 1. Genotyping of the mutation was performed by SSCP with primer set 2, and the corresponding three genotypes were named GG, GT, and TT (Figure 1). Products with three genotypes were sequenced respectively for sake of avoiding the false positive of SSCP (Figure 2). The frequencies of the $\mathrm{G}$ and $\mathrm{T}$ alleles were 0.398 and 0.602 , respectively, and the frequencies of the GG, GT, and TT genotypes were $0.150,0.496$, and 0.354 , respectively.

\section{Association of genotypes with superovulation traits}

The numbers of non-responders with the GG, GT, and TT genotypes were 2,7 , and 4 respectively. The results of association analysis between genotypes and superovulation traits are shown in Table 1. Heifers with the GG and GT genotypes had a significantly higher total number of ova (TNO) than those with the TT genotype $(P<0.05)$, and heifers with the GG genotype had a significantly higher number of transferable embryos (NTE) than those with GT and TT $(P<0.05)$. Heifers with the GG genotype had a smaller number of unfertilized ova (NUO) than those with the GT and TT genotypes, although only the difference between GG and GT was significant. There were no significant differences in the number of degenerate embryos (NDE) among the three genotypes.

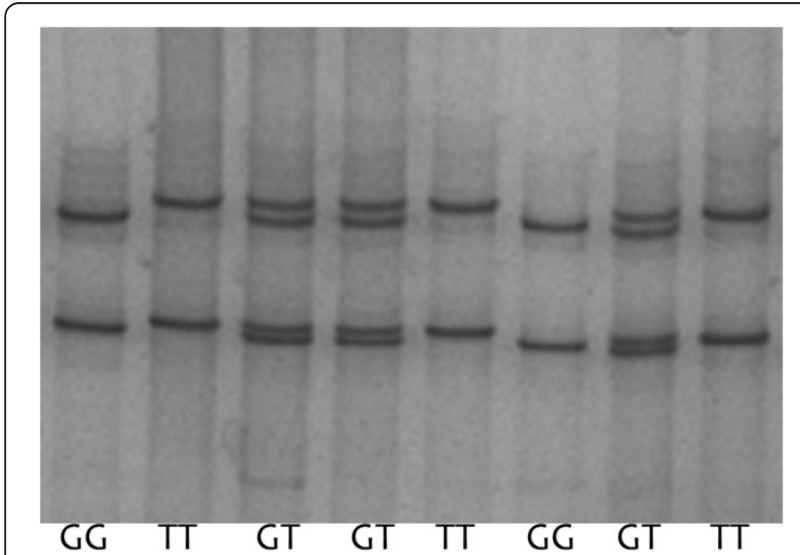

Figure 1 Representative genotyping of LHCGR by SSCP followed by polyacrylamide gel electrophoresis. A single mutation reveals three genotypes: four bands numbered 1, 2, 3 and 4 from bottom up in one lane make the GT genotype, No.1 and No.3 bands make the GG genotype, and No.2 and No.4 bands make the $\Pi$ genotype.

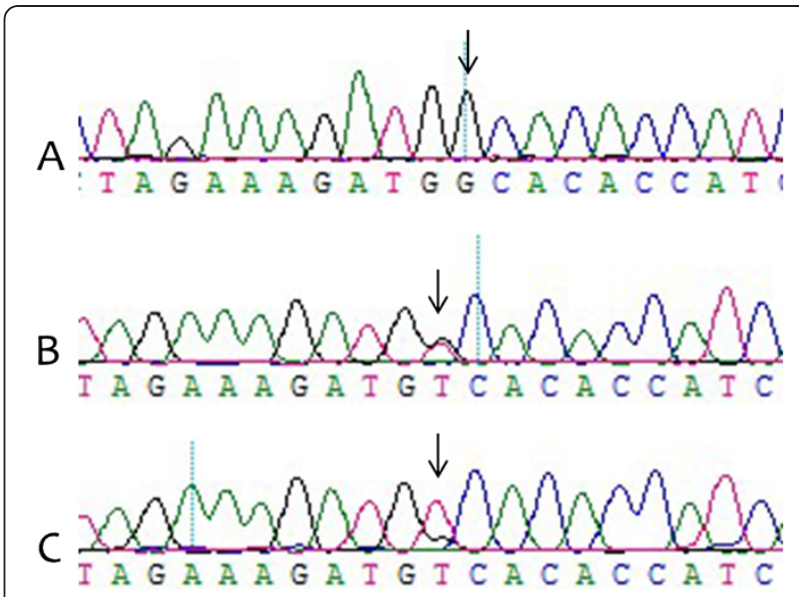

Figure $2 \mathrm{~A}, \mathrm{~B}$ and $\mathrm{C}$ represent sequencing results of products with GG, GT and TT genotypes respectively. Arrows indicate the mutation site.

\section{Discussion}

The use of peripubertal donors in embryo transfer (ET) programs has been studied, and no differences in TNO or NTE have been found among heifers that were older than 10 months of age [24]. Furthermore, reproductive and lactational traits of heifers subjected to embryo transfer do not differ from their untreated full siblings [24]. Thus, the heifers in this study can be used as donors in embryo transfer programs without compromising their subsequent reproductive or lactational performance [24]. Hayakawa et al. (2009) compared the outcomes of superovulation and embryo transfer with sexed and unsexed sperm and observed no difference between the two groups for superovulation traits or pregnancy rates [25]. These observations are consistent with results of our previous study [26]. For AI in our study, sexed frozen-thawed sperm from different bulls was used randomly to inseminate heifers.

Heifers with the GG genotype had significantly higher TNO and NTE than those with the TT genotype, indicating that the $\mathrm{G}$ allele had a favorable, positive effect on these two superovulation traits. Three SNPs (ss52050737,

Table 1 Association of LHCGR genotypes with
superovulation traits
\begin{tabular}{lcccc}
\hline Traits & GG (17) & & \\
\hline TNO & $10.989 \pm 1.517^{\mathrm{b}}$ & $10.287 \pm 0.889^{\mathrm{b}}$ & $7.036 \pm 1.057^{\mathrm{c}}$ & 0.020 \\
$\mathrm{NTE}$ & $6.615 \pm 1.020^{\mathrm{b}}$ & $4.262 \pm 0.686^{\mathrm{bd}}$ & $3.246 \pm 0.836^{\mathrm{d}}$ & 0.008 \\
$\mathrm{NUO}$ & $1.518 \pm 0.826^{\mathrm{b}}$ & $3.445 \pm 0.555^{\mathrm{c}}$ & $2.479 \pm 0.677^{\mathrm{bc}}$ & 0.046 \\
$\mathrm{NDE}$ & $2.175 \pm 0.866$ & $2.086 \pm 0.582$ & $1.434 \pm 0.710$ & 0.557 \\
\hline
\end{tabular}

${ }^{a}$ The number of samples is shown in parentheses. All data in the table are least square means \pm SE. Different superscript letters $(b-d)$ in the same row indicate significant differences $(P<0.05)$. TNO: total number of ova; NTE: number of transferable embryos; NUO: number of unfertilized ova; NDE: number of degenerate embryos. 
ss52050738, and ss52050739) in exon 11 of LHCGR and their significant associations with variations in cattle fertility were described [22], and our results further demonstrated the SNP (ss52050737), in particular, was associated with a positive response to superovulation.

As a response to superovulatory treatment in cattle, more ovarian follicles initiate growth, granulosa cells proliferate and acquire follicle stimulating hormone receptors, and LHRs are induced, permitting the granulosa cells to later respond to LH [1]. Subsequently, several events occur: resumption of oocyte meiosis, transformation of the steroid enzyme complex from production of estrogen to production of progesterone, follicular rupture, and finally corpus luteum formation when serum LH levels increase during the preovulatory LH surge [1]. In cattle, moreover, LH may promote cytoplasmic maturation or competence of the oocyte as well as embryonic development after fertilization, both in vivo and in vitro $[4,5,27,28]$. The presence of LHRs in bovine oocytes, embryos, and blastocysts has been reported[5]. Bovine oviducts also express LHRs, and their activation results in increased synthesis of oviductal glycoprotein [29], which binds to embryos to enhance their development [30-34]. Thus, LH may enhance embryonic development through both direct and indirect mechanisms after binding to its receptor. As a G protein-coupled receptor, binding of the LHCGR allows dissociation of membrane-bound cognate $G$ proteins that regulate phospholipase $\mathrm{C}$, adenylyl cyclase, and ion channels, which in turn control cellular inositol phosphates, cAMP, $\mathrm{Ca}^{2+}$, and other secondary messengers [8]. Exon 11, in which SNP ss52050737 is located, encodes the intracellular domain of the LHCGR protein. Therefore, a missense mutation may change the structure of the intracellular region of the LHCGR and reduce the effect of LH to explain the functional relevance of this mutation to variation in response to superovulation and phenotype. However, the biological mechanism by which the mutation influences the function of LHCGR requires further investigation.

\section{Conclusions}

The results of this study indicate that LHCGR is a potential marker for superovulation traits and can be used as a predictor for superovulation in Chinese Holstein heifers.

\section{Competing interests}

The authors declare that they have no competing interests.

\section{Authors' contributions}

Yong Yu participated in experimental design, data collection, analysis of the data and manuscript preparation; Yunwei Pang was responsible for research design, analysis of the data and draft the manuscript; Haichao Zhao helped for data collection and coordinated the research; Xiaoling Xu helped for analysis of the data; Zhonghong Wu helped for manuscript revising; Lei an help with data collection; Jianhui Tian contributed in experimental design and made the reasonable corrections on the manuscript. All authors read and approved the final manuscript.

\section{Acknowledgements}

We thank Yulin Zhu and Bohua Xuan of the Beijing Dairy Cattle Center for their help in sampling and collecting data from the heifers. We are also grateful to Dr. Qin Zhang for help with the statistical analyses. This study was supported by grant \#2011BAD19B01, \#2011BAD19B03 and \#2011BAD19B04 from the National Key Technology R\&D program; \#2011AA100303 from National High-Tech R\&D Program.

Received: 6 April 2012 Accepted: 7 August 2012

Published: 9 November 2012

\section{References}

1. Channing CP, Schaerf FW, Anderson LD, Tsafriri A: Ovarian follicular and luteal physiology. Int Rev Physiol 1980, 22:117 -201.

2. Channing CP, Hillensjo T, Schaerf FW: Hormonal control of oocyte meiosis, ovulation and luteinization in mammals. Clin Endocrinol Metab 1978, 7:601-624.

3. Peters KE, Bergfeld EG, Cupp AS, Kojima FN, Mariscal V, Sanchez T, Wehrman $M E$, Grotjan HE, Hamernik DL, Kittok RJ: Luteinizing hormone has a role in development of fully functional corpora lutea (CL) but is not required to maintain CL function in heifers. Biol Reprod 1994, 51:1248-1254.

4. Gliedt DW, Rosenkrans CF Jr, Rorie RW, Munyon AL, Pierson JN, Miller GF, Rakes JM: Effects of media, serum, oviductal cells, and hormones during maturation on bovine embryo development in vitro. J Dairy Sci 1996, 79:536-542.

5. Mishra S, Lei ZM, Rao Ch V: A novel role of luteinizing hormone in the embryo development in cocultures. Biol Reprod 2003, 68:1455-1462.

6. Dufau ML, Tsai-Morris $\mathrm{CH}$, Hu ZZ, Buczko E: Structure and regulation of the luteinizing hormone receptor gene. J Steroid Biochem Mol Biol 1995, 53:283-291.

7. Gudermann T, Birnbaumer M, Birnbaumer L: Evidence for dual coupling of the murine luteinizing hormone receptor to adenylyl cyclase and phosphoinositide breakdown and $\mathrm{Ca} 2+$ mobilization. Studies with the cloned murine luteinizing hormone receptor expressed in L cells. J Biol Chem 1992, 267:4479-4488.

8. Loosfelt H, Misrahi M, Atger M, Salesse R, Vu Hai-Luu Thi MT, Jolivet A, Guiochon-Mantel A, Sar S, Jallal B, Garnier J: Cloning and sequencing of porcine LH-hCG receptor CDNA: variants lacking transmembrane domain. Science 1989, 245:525-528

9. McFarland KC, Sprengel R, Phillips HS, Kohler M, Rosemblit N, Nikolics K, Segaloff DL, Seeburg PH: Lutropin-choriogonadotropin receptor: an unusual member of the G protein-coupled receptor family. Science 1989, 245:494-499.

10. Minegishi T, Nakamura K, Takakura Y, Miyamoto K, Hasegawa Y, Ibuki Y, Igarashi M, Minegish T: Cloning and sequencing of human LH/hCG receptor cDNA. Biochem Biophys Res Commun 1990, 172:1049-1054

11. Aatsinki JT, Pietila EM, Lakkakorpi JT, Rajaniemi HJ: Expression of the LH/CG receptor gene in rat ovarian tissue is regulated by an extensive alternative splicing of the primary transcript. Mol Cell Endocrinol 1992, 84:127-135.

12. Abdennebi L, Lesport AS, Remy JJ, Grebert D, Pisselet C, Monniaux D, Salesse R: Differences in splicing of mRNA encoding LH receptor in theca cells according to breeding season in ewes. Reproduction 2002, 123:819-826.

13. Bacich DJ, Rohan RM, Norman RJ, Rodgers RJ: Characterization and relative abundance of alternatively spliced luteinizing hormone receptor messenger ribonucleic acid in the ovine ovary. Endocrinology 1994, 135:735-744.

14. Nogueira MF, Buratini J Jr, Price CA, Castilho AC, Pinto MG, Barros CM: Expression of LH receptor mRNA splice variants in bovine granulosa cells: changes with follicle size and regulation by FSH in vitro. Mol Reprod Dev 2007, 74:680-686.

15. Robert C, Gagne D, Lussier JG, Bousquet D, Barnes FL, Sirard MA: Presence of $\mathrm{LH}$ receptor mRNA in granulosa cells as a potential marker of oocyte developmental competence and characterization of the bovine splicing isoforms. Reproduction 2003, 125:437-446. 
16. Mapletoft RJ, Hasler JF: Assisted reproductive technologies in cattle: a review. Rev Sci Tech 2005, 24:393-403.

17. Mapletoft RJ, Steward KB, Adams GP: Recent advances in the superovulation in cattle. Reprod Nutr Dev 2002, 42:601-611.

18. Barros CM, Ereno RL, Simoes RA, Fernandes P, Buratini J, Nogueira MF: Use of knowledge regarding $\mathrm{LH}$ receptors to improve superstimulatory treatments in cattle. Reprod Fertil Dev 2010, 22:132-137.

19. Yang WC, Li SJ, Tang KQ, Hua GH, Zhang CY, Yu JN, Han L, Yang LG: Polymorphisms in the 5' upstream region of the FSH receptor gene, and their association with superovulation traits in Chinese Holstein cows. Anim Reprod Sci 2010, 119:172-177.

20. Tang KQ, Li SJ, Yang WC, Yu JN, Han L, Li X, Yang LG: An Mspl polymorphism in the inhibin alpha gene and its associations with superovulation traits in Chinese Holstein cows. Mol Biol Rep 2011, 38:17-21.

21. Yang WC, Tang KQ, Li SJ, Yang LG: Association analysis between variants in bovine progesterone receptor gene and superovulation traits in Chinese Holstein cows. Reprod Domest Anim 2011, 46:1029-1034.

22. Hastings N, Donn S, Derecka K, Flint AP, Woolliams JA: Polymorphisms within the coding region of the bovine luteinizing hormone receptor gene and their association with fertility traits. Anim Genet 2006, 37:583-585.

23. Yang WC, Tang KQ, Li SJ, Chao LM, Yang LG: Polymorphisms of the bovine luteinizing hormone/choriogonadotropin receptor (LHCGR) gene and its association with superovulation traits. Mol Biol Rep 2012, 39:2481-2487.

24. Ax RL, Armbrust S, Tappan R, Gilbert G, Oyarzo JN, Bellin ME, Selner D, McCauley TC: Superovulation and embryo recovery from peripubertal Holstein heifers. Anim Reprod Sci 2005, 85:71-80.

25. Hayakawa H, Hirai T, Takimoto A, Ideta A, Aoyagi Y: Superovulation and embryo transfer in Holstein cattle using sexed sperm. Theriogenology 2009, 71:68-73.

26. An L, Wu ZH, Wu YF, Zhang XL, Liu X, Zhu YB, Cheng WM, Gao HM, Guo M, Tian JH: Fertility in single-ovulating and superovulated dairy heifers after insemination with low dose sex-sorted sperm. Reprod Domest Anim 2010, 45:e344-e350

27. Chaubal SA, Ferre LB, Molina JA, Faber DC, Bols PE, Rezamand P, Tian X, Yang $X$ : Hormonal treatments for increasing the oocyte and embryo production in an OPU-IVP system. Theriogenology 2007, 67:719-728.

28. Lindsey BR, Maclellan $L$, Whyte TR, Kinder JE, D'Occhio MJ: Differential requirement for pulsatile LH during the follicular phase and exposure to the preovulatory LH surge for oocyte fertilization and embryo development in cattle. Theriogenology 2002, 58:1651-1662.

29. Sun T, Lei ZM, Rao CV: A novel regulation of the oviductal glycoprotein gene expression by luteinizing hormone in bovine tubal epithelial cells. Mol Cell Endocrinol 1997, 131:97-108.

30. Boice ML, McCarthy TJ, Mavrogianis PA, Fazlebas AT, Verhage HG: Localization of oviductal glycoproteins within the zona pellucida and perivitelline space of ovulated ova and early embryos in baboons (Papio anubis). Biol Reprod 1990, 43:340-346.

31. Boice ML, Mavrogianis PA, Murphy CN, Prather RS, Day BN: Immunocytochemical analysis of the association of bovine oviductspecific glycoproteins with early embryos. J Exp Zool 1992, 263:225-229.

32. Buhi WC, O'Brien B, Alvarez IM, Erdos G, Dubois D: Immunogold localization of porcine oviductal secretory proteins within the zona pellucida, perivitelline space, and plasma membrane of oviductal and uterine oocytes and early embryos. Biol Reprod 1993, 48:1274-1283.

33. Gandolfi F, Modina S, Brevini TA, Galli C, Moor RM, Lauria A: Oviduct ampullary epithelium contributes a glycoprotein to the zona pellucida, perivitelline space and blastomeres membrane of sheep embryos. Eur $J$ Basic Appl Histochem 1991, 35:383-392.

34. Nancarrow $C D$, Hill JL: Oviduct proteins in fertilization and early embryo development. J Reprod Fertil Supp/ 1995, 49:3-13.

doi:10.1186/2049-1891-3-35

Cite this article as: Yu et al:: Association of a missense mutation in the luteinizing hormone/choriogonadotropin receptor gene (LHCGR) with superovulation traits in Chinese Holstein heifers. Journal of Animal Science and Biotechnology 2012 3:34.

\section{Submit your next manuscript to BioMed Central and take full advantage of:}

- Convenient online submission

- Thorough peer review

- No space constraints or color figure charges

- Immediate publication on acceptance

- Inclusion in PubMed, CAS, Scopus and Google Scholar

- Research which is freely available for redistribution 